\title{
Urban Crime Control and Prevention in the 1990s: Community Policing
}

\author{
Jevera R. Temskyt
}

Jevera Temsky is a second-year master of public administration student concentrating in women and public policy. Ms. Temsky received a bachelor's degree in comparative politics and women's studies from Clark University in 1985.

Crime in the United States has captured the nation's attention and defined domestic political priorities, compelling us to reexamine even such simple daily activities as taking a walk or sending children to school. Although 93 percent of the respondents to a recent poll cited by the Federal Bureau of Investigation (FBI) reported that the crime problem should be a top priority for the federal government, the overall crime rate in the United States actually dropped between 1991 and 1993.' What bas gone up is the rate of violent crime. ${ }^{2}$ According to the $\mathrm{FBI}$, more than fourteen million crimes were reported in 1993, with one violent crime committed every sixteen seconds. ${ }^{3}$ Not only have crime rates risen, the fear of crime has also increased. This fear is leading to considerable personal, social, and economic costs and can actually contribute to the crime problem by diminishing the ability of communities to deter crime. ${ }^{4}$

Community policing seeks to control both the crime rate and the spreading fear that is almost as detrimental. The philosophy of community policing attributes increased criminal behavior to poverty, poor education, unemployment or unstable employment, the easy availability of guns and drugs, and the disintegration of social systems." Community policing advocates believe that crime fighting techniques must match the complexity of the crime problem itself and that success will occur in direct relation to the restoration of the poor social and economic systems within which criminals and would-be criminals live, Community-police partnerships are the cornerstone of this philosophy and community policing initiatives have demonstrated great potential for cooperative crime fighting in urban areas, which have the highest crime rates in the country.

Crime has emerged as a perennial challenge during a period when both politicians and voters are frustrated by the complexity of the problems facing society. Law enforcement professionals and legislators at local, state, and national levels agree that cities in the United States have a serious crime problem, but they have not reached consensus on the best actions to resolve this crisis. This lack of agreement is due both to different perceptions of the causes of crime and to differing ideas about solutions to the crime problem. A basic philosophical dichotomy exists between those who favor programs that seek to deter crime by punitive tactics such as increased use of physical force and lengthened sentencing for convicted criminals, and advocates of programs like community policing that are designed to alter the conditions that foster the development of criminals.

While a study comparing community policing to other types of anti-crime initiatives would be both interesting and valuable, this article is limited in scope to a general discussion of community policing and an examination of specific programs, A history of police reform will be followed by discussion of some challenges to community policing, including arguments about its ability to control and deter crime and the federal government's disputed role in urban crime control and prevention. The article will conclude with comments on the future of community policing in the United States.

\section{Community Policing}

Community policing is a philosophy that seeks to fight crime through citizen empowerment and problem identification and solution. (see Fig. 1) The philosophy gained prominence in the early 1980s, an era when police officers and citizens were alienated from each other both physically and psychologically. ${ }^{7}$ Officers spent much of their time in patrols cars, and many law enforcement agents believed the community was more likely to collude with criminals 


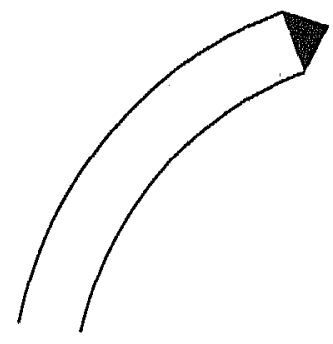

TRUST

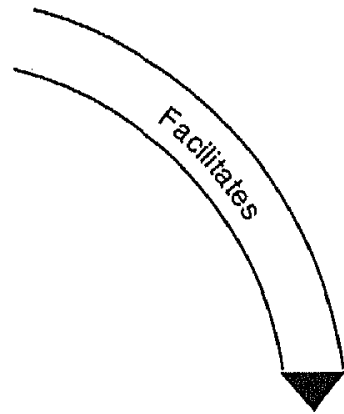

COMMUNICATION

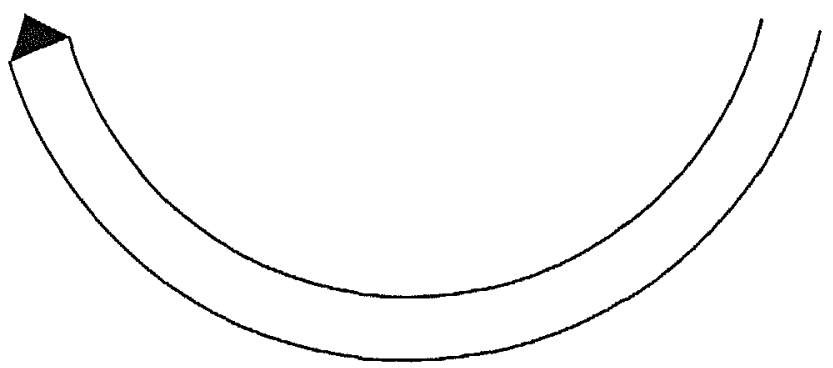

Figure 1: Community Partnership Process Reprinted with permission, Bureau of Justice Assistance, Office of Justice Programs, U.S. Department of Justice

than to work with police to prevent crime. ${ }^{8}$ Community policing addresses the problem by advocating that citizenpolice cooperation is essential to successful crime fighting. While police administrators may develop important ties with the community, police officers are the principle points of contact with the public. As described by the Nationat Center for Community Policing at Michigan State University, the Community Police Officer (CPO) is

a full-fledged law enforcement officer who makes arrests, but the challenge in the job is also to find new ways to address old problems. The CPO's direct, daily contact with average citizens in the community means that together they can prioritize local needs and develop creative community-based, police-supervised initiatives aimed at providing short- and longterm improvements in the overall quality of life. ${ }^{9}$

No law enforcement training can serve as a substitute for the knowledge and commitment possessed by the residents of a neighborhood; thus, the police must work with community residents as partners. Community residents are familiar with the unique patterns of life on the street, have a vested interest in making an area safe, and often have personal relationships with those members of the community who have turned to criminal activity as a way of life. Once police establish communication with citizens, law

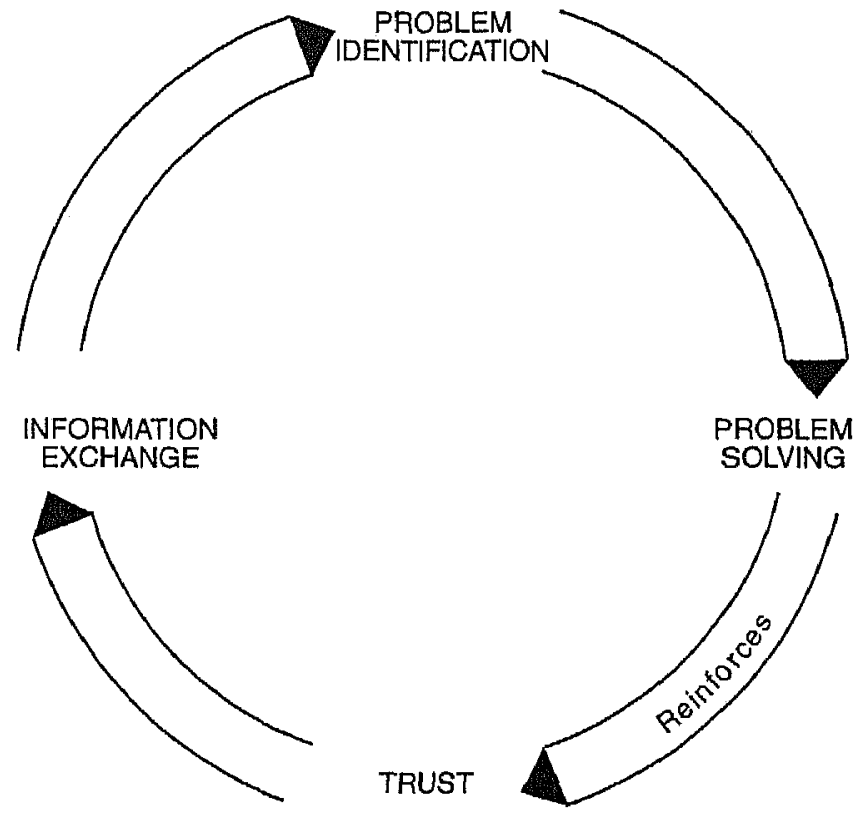

Figure 2: Problem-Solving Process

Reprinted with permission, Bureau of Justice Assistance, Office of Justice Programs, U.S. Department of Justice

enforcement personnel have access to an invaluable source of information; residents can help police both to apprehend criminals and to focus resources on basic problems that may not be obvious to outside observers..$^{10}$ (see Fig. 2)

Community policing has become an accepted practice in the United States, with the majority of larger police departments indicating that they either have or plan to implement some form of community policing. ${ }^{11}$ Programs usually share some fundamental elements: community-police cooperation, intergovernmental support, and partnerships with local business, educational, and religious institutions. Each department follows a specially formulated set of priorities based on the specific needs and resources of each urban area, with law enforcement officers maintaining the key relationships that could lead to long-term crime prevention and control.

\section{History of Police Reform}

Because police play a central role in our society, the challenges facing the law enforcement community are closely related to social, political, and economic forces in operation throughout the country. In particular, just as all public leaders have struggled to effectic cly manage human resources, to provide equal empleyment opportunities to 
women and racial minorities, and to deliver public services equitably, controversies over law enforcement administration have continued throughout the evolution of policing in the United States. Community policing is located on a continuum of social reform that began after the Civil War when police forces in both the northern and southern United States served not only to prevent crime, but also to reinforce systems of power. ${ }^{12}$

\section{A basic philosopbical dichotomy exists between those who favor programs that seek to deter crime by punitive tactics... and advocates of programs like community policing that are designed to alter the conditions that foster the development of criminals.}

Progressive reformers made the first successful attempt at broad police reform. According to the reformers, politicians wielded excessive control over police departments and police officers were criticized for exercising too much individual discretion in the performance of duties.

Reformers advocated the centralization of management in order to eliminate the direct influence of corrupt politicians on officers. ${ }^{13}$

Reformers began a process of professionalizing police work and centralizing police management as part of the civil service reforms of the mid-1940s. ${ }^{14}$ During the next twenty years, police departments formed specialized units that utilized new technology to standardize both record keeping and crime fighting. Because directives came from a central office, misuse of power by individual officers was minimized, even though officers became distanced from the people they were supposed to monitor and protect. ${ }^{15}$ Mid-century police reform failed to preserve such hard-toquantify but critical elements of police work as the need for trust and cooperation between the community and law enforcement personnel.

Progressive reformers did not seek to improve race relations either within police departments or between the police and the public. Few northern states and no southern states had black officers during the late 19th and early 20th centuries. In "The Evolving Strategy of Police: A Minority View," Hubert Williams and Patrick Murphy explain that the legal guidelines that made a civil service corps more desirable than a police force based in political patronage had little effect on minorities:

As dramatic as this change must have appeared to the white middle-class inhabitants of America's major cities, the transition to the reform era was barely noticeable to blacks and other minorities. Relying on law, rather than politics, as the source of police authority had many desirable aspects for those provided full protection by the law...for those who lacked both political power and equal protection under the law, such a transformation could have little significance. $^{16}$

Just as Blacks, Puerto Ricans, and members of other minority groups made few gains in employment during this era of racial segregation, minority communities did not benefit from the professionalization of police officers and the centralization of management. Because officers no longer maintained direct contact with the street, community members lost the opportunity to develop a relationship, however stormy, with a member of the police force. Racial barriers were reinforced during the reform era, and police departments entered the 1960 s ill-prepared to face the turbulence ahead.

In Working the Streets, Michael J. Brown explains how a major challenge to the law enforcement community came amid the social upheaval of the early 1960s, during the War on Poverty and the Vietnam War:

Criticism of the decision to expand the war in Vietnam led to criticism of American foreign policy since World War II; the decision to embark on a war on poverty and the riots in American cities focused attention on the urban crisis. The police were important figures in both conflicts. The conduct of the police in handling demonstrations against the Vietnam War during these years became a matter of controversy as did the relationship between the police and the poor black and Mexican-American residents of the inner city. ${ }^{17}$

Against a backdrop of the Civil Rights movement and other challenges to power structures, popular discontent with law enforcement propelled concern with local crime to the federal level. Barry Goldwater made crime a presidential campaign issue for the first time during the 1964 race with Lyndon Johnson. After his election, President Johnson created first the Commission on Law Enforcement and Administration and subsequently the Commission on the Causes and Prevention of Violence. ${ }^{18}$ Both commissions put particular emphasis on the urban crime problem and 
suggested that the federal government increase spending not only to fight crime but also to provide urban social welfare programs in order to address the "increasingly powerful social forces [that] are generating rising levels of violent crime which, unless checked, threaten to turn our cities into defensive, fearful societies." ${ }^{19}$

\section{Clearly, in order to make a difference, the police must form working partnerships in the community...}

Despite increased federal spending on social welfare and crime fighting, crime rates rose during the 1970s. During the Nixon administration, federal crime fighting measures paid less attention to the social causes of crime and began to emphasize law enforcement and punishment of those accused of breaking the law. ${ }^{20}$ Under the leadership of Ronald Reagan, Congress passed the Comprehensive Crime Control Act of 1984, which exemplified this shift.. ${ }^{21}$

While political leaders tried to control crime through tougher treatment of criminals, professional law enforcement organizations, academics, and police departments conducted research to better understand the crime problem. Much of their work focused on the need to address racial inequality within law enforcement organizations and to learn about the racial and ethnic composition of the communities to be served. Police departments complied with equal employment guidelines and diversified their forces by hiring racial minorities and women. ${ }^{22}$

In addition to highlighting internal needs, reports identified several areas of weakness in police work on the street. In particular, police officers spent a majority of their time on the street responding to calls rather than preventing criminal acts from occurring. Researchers also noted that citizens, particularly in poor urban areas, saw police as adversaries. This led to a reluctance to cooperate with police, including a failure to report crime in a timely manner. ${ }^{23}$

Police departments experimented throughout the 1970 s and early 1980s with different strategies to fight crime that drew on community resources. In 1979, Herman Goldstein of the University of Wisconsin School of Law developed "problem-oriented policing" (POP), an approach that directed police to search for the underlying causes of repeat service calls and work to eliminate those causes, not just respond to their effects. POP laid the groundwork for widespread innovation in the development of commu- nity-oriented, proactive crime prevention strategies, with police forces in Baltimore, Maryland; Madison, Wisconsin; and Houston, Texas, among the first cities to test Goldstein's ideas. ${ }^{24}$

Through systematic study of various approaches to crime control and prevention, the law enforcement community developed what is now termed community policing. Justification for adopting this new approach was summed up effectively by Lee Brown, the former Police

Commissioner for New York City. At a meeting of the FBI Conference on Violent Crime and Community Involvement four years ago, Brown explained his enthusiasm for the philosophy:

Today's police officer contends with the debris of social and institutional collapse...Faced with the uncertainties and instability that stem from these social and institutional failures, the police officer's job is more demanding and complex than ever before. Clearly, in order to make a difference, the police must form working partnerships in the community, and use all the resources of government, business, the schools-all the resources available to it-to try to resolve some of the recurring problems.

Otherwise, we will function only as incident responders, never getting to the root causes of crime, violence and fear. ${ }^{25}$

\section{Criticisms of Community Policing}

Although many police administrators, officers, and academics support community policing programs, critics still question the value of these strategies. Criticism ranges from fear that foot patrol officers will be slow to respond to crisis calls to concern that community policing will turn law enforcement officers into social workers.

The effectiveness of any method of crime control-including community policing-is difficult to measure because of the many factors associated with crime. For example, statistics based on the number of arrests in a given time period may only provide a gauge of police activity, not whether that activity was justified and would lead to decreased crime rates. As law enforcement expert Richard E. Overman noted:

We have traditionally measured our success or failure based on statistics: number of arrests, number of summonses, etc. Based on such statistical criteria, it would be hard to say we have not been successful; indeed, we are probably the most efficient compo- 
nent of the justice system. But perhaps we have been measuring the wrong things. The average citizen does not care whether you made five or 50 arrests on his corner for crack cocaine sales; what he cares about is whether it is still possible to buy cocaine on the corner. We must go beyond the traditional approaches and begin to judge our effectiveness by the condition of the corner rather than by the number of arrests. ${ }^{26}$

Community policing presents additional measurement problems because this form of law enforcement occurs as part of a community system with numerous variables, each impossible to control, simultaneously at play. While guidelines have been developed for police departments to check the progress of community policing programs, many measurement tools only help police administrators gauge whether or not police officers are successfully implementing the philosophy, rather than assessing the impact of community policing on crime rates. ${ }^{27}$ In spite of these difficulties, some meaningful evaluation can be conducted of the crime fighting ability of police departments that use community police officers.

One way police officers' effectiveness may be judged is by their ability to respond quickly when needed. Community policing has come under criticism because community police officers use their time differently than traditional police officers. For example, foot patrol officers may answer emergency calls more slowly than officers cruising an area by patrol car. Officers who are busy with community empowerment programs may not be as available to answer emergency calls as police officers whose duties are more traditional.

Concerns about the loss of rapid response can be addressed in two ways. One way to decide if slower response time makes community policing an ineffective law enforcement tool is to examine the belief that rapid response is critical to effective crime fighting. According to the National Institute of Justice (NIJ):

Rapid response is not as important as previously believed because there generally is an extended delay before citizens call the police. A rapid police response is important only in the small percentage of cases where a life is being threatened or apprehension of the suspect is possible. ${ }^{28}$

In these cases, community police officers can compensate for lost response time through strategic use of modern telecommunications devices such as mobile phones and laptop computers. ${ }^{29}$

A second way to address concerns-perhaps more important than a discussion of ways to maintain and improve rapid response capability--is to decide if rapid response ought to be a primary goal of policing. Certainly when lives are at stake, or when swift action on the part of police is likely to result in the arrest of a criminal, rapid response is critical. But between 50 and 90 percent of 911 calls are not about crime, and of those calls that do refer to crime, less than 5 percent require immediate response. Police departments can utilize tools other than rapid response to handle these non-crisis calls. ${ }^{30}$ By shifting from rapid response to managed or "differential police" response, community police officers will be free to do the proactive work that may actually lessen the number of crises. ${ }^{31}$

\section{Between 50 and 90 percent of 911 calls are not about crime, and of those calls that do refer to crime, less than 5 percent require immediate response.}

NIJ conducted differential police response experiments in the early 1980s to challenge the assumption that citizen satisfaction with police work is tied to rapid response. Police dispatchers in California, North Carolina, and Ohio were trained to rank calls and inform the public about estimated response time to non-emergency requests for police service. More than 90 percent of callers who received alternative responses reported satisfaction with the new approach, and police on patrol found their workload decreased by one-fifth. The Reno, Nevada, police department not only utilizes call management but also has police officers split their day between community mobile response and outreach projects, thus enabling officers to serve both as reactive and proactive agents. ${ }^{32}$

Another major criticism of community policing is that the philosophy changes the role of the police officer from crime fighter to social worker. This criticism may reflect a misunderstanding of the philosophy of community policing. Though community police officers are expected to maintain cooperative relationships with the communities they serve, officers engage in community development work in addition to, not instead of, their regular duties. Unlike social workers, parents, teachers, politicians, and clergy, community police officers are agents whose power to act in the name of the state legally extends to the use of 
deadly force. ${ }^{33}$ Like traditional police officers, community police officers have entree to all strata of society and have access to considerable public funds. ${ }^{34}$ Community police officers can leverage this unique professional position to foster citizen-police partnerships that are tightly focused on problem identification, crime control, and prevention.

Numerous instances can be cited where police identified and solved problems because they had formed cooperative relationships with community members. The Seattle, Washington, police department demonstrated how a citizen-police partnership worked to curb crack cocaine dealing and use in Rainier Valley, a low-income, largely minority community in the southeast part of the city. During the 1980s, police tried unsuccessfully to stem the flow of illegal drug use and sale, as well as curb drug-related crime. After several years of working with the community, the police department set up a hotline for residents to report information about drug activity. Police verified "intelligence" gathered from these reports and made a strategic plan to target, among other sites, twenty crack houses. Most of these houses were closed within a year. Because drug dealers from raided crack houses can easily move and restart operations, the fight against crack now depends on the ongoing coordinated efforts of both police and citizens in Rainier Valley. ${ }^{35}$

Community-police partnerships can prove invaluable when police are trying to stem crime in multiracial neighborhoods, particularly where police and residents have had a troubled relationship in the past. The Los Angeles police department relied on community cooperation to fight crime through community policing on Blythe Street, a poor Latino neighborhood whose residents tend to have low English skills, high unemployment, and, according to Officer Stephen Margolis of the Los Angeles Police Department, "an unbroken cycle of multi-generational gang violence supporting around-the-clock narcotics trafficking." ${ }^{136}$ By working with social service agencies, churches, and teachers to bring a variety of much-needed services to Blythe Street, police sent a clear message that they valued the community and wanted to help improve life on the block. Police efforts yielded positive results:

The community responded in kind, embracing the effort and reciprocating trust. The breakthrough was evident when residents, after generations of distrust of governments, provided police officers with information about gang and narcotics activities. ${ }^{37}$

In spite of the demonstrated effectiveness of community policing, police departments may find it difficult to finance implementation of the philosophy, particularly if programs involve foot patrols. Law enforcement is costly, and the largest expense in police force budgets is personnel. In 1994 , the typical salary for a police officer was fifty thousand dollars. ${ }^{33}$ In 1990 , there were 222 local police departments serving communities of one hundred thousand or more citizens. If each of these departments were to increase their forces by 20 percent, their combined spending would be approximately one billion dollars per year. ${ }^{39}$ Urban leaders who consider implementing community policing strategies must decide if the social benefits will offset these costs.

\section{Though community police officers are expected to maintain cooperative relationships with the communities they serve, officers engage in community development work in addition to, not instead of, their regular duties.}

An alternative to investing more money in police officers for community policing is to find ways to employ human resources already at the disposal of the department. Just as police departments have had success at overhauling rapid response systems to make more efficient use of officers' time, cities in several parts of the country have changed deployment patterns by eliminating middle-management positions and moving law enforcement personnel from central headquarters and specialized units to the street. For example, when Lee Brown took over as Police Chief of Houston, he put almost five hundred officers back on patrol. The police department in Reno, Nevada, made more officers available for problem-solving and community contact by reducing supervisory personnel between the ranks of chief and area captain. ${ }^{40}$

\section{The Federal Role}

As discussed earlier, the federal government has been directly involved in local crime control since the 1960s. At the close of the twentieth century, both the federal government and local governments agree that the federal government should continue this involvement, but Democrats and Republicans disagree about how federal funding for local law enforcement should be disbursed and spent. Democrats have advocated tying the receipt of federal funds to local development of community policing pro- 
grams, while Republicans favor block grant funding to be used at the discretion of state and local law enforcement agencies.

In August 1994, Congress passed the Violent Crime and Law Enforcement Act of 1994, a sweeping crime control package that addresses everything from violence against women to prison construction. Of the $\$ 30.2$ billion authorized by the bill, $\$ 6.9$ billion is earmarked for crime prevention programs during the next six years. ${ }^{11}$ An important section of the Crime Act, entitled Community Policing: 'Cops on the Beat,' outlines federal support for community policing. The Act authorizes the Attorney General to grant funds

to increase police presence, to expand and improve cooperative efforts between law enforcement agencies and members of the community to address crime and disorder problems, and otherwise to enhance public safety. ${ }^{42}$

Applications for these Public Safety and Community Policing Grants must "include a long-term strategy and detailed implementation plan that reflects consultation with community groups and appropriate private and public agencies. ${ }^{1 / 3}$ Grant recipients can use federal funds for rehiring law enforcement officers who lost their jobs due to local funding shortages, to hire and train new Community Police Officers (CPOs), to buy new equipment or enhance existing technology, and to pay overtime to keep an adequate number of $\mathrm{CPO}$ on the street.

Although the Act demonstrates strong federal approval of community policing as a crime- fighting tool, the $\$ 1.3$ billion allocated to fund up to 75 percent of any local community policing program may, ironically, do more harm than good to local budgets in the long run. ${ }^{44}$ These funds phase out over six years, after which time grant recipients must find continued funding from "State or local sources." In other words, communities that apply for community policing grants must be prepared to quickly shoulder the complete financial burden for new hires and programs.

Public Safety and Community Policing Grants also contain high administrative, implementation, and monitoring costs. Under the crime act, applicants will prepare extensive grant application materials that include detailed plans for how federal money will be spent. Once a program is under way, the local recipient is required to conduct "systematic identification and collection of data about activities, accomplishments, and programs throughout the life of the program, project or activity and present...such data in usable form." ${ }^{\text {"h }}$ One potential grant recipient estimated a loss of 15 percent of federal funding to administrative overhead. ${ }^{17}$

Even if a significant portion of federal funds is not used for administrative purposes, "Cops on the Beat" may not help cities find long-term solutions to the crime problem. The act makes funds for community policing available to a wide assortment of local governments and similar jurisdictions. ${ }^{48}$ According to Dr. John Dilulio of Princeton University and the Brookings Institution, if a program is to help the most crime-ridden areas, federal funds should not be disbursed so broadly:

Most communities need more cops about as much as Washington needs more lobbyists. Instead, what is needed is saturation community-based policing of America's most drug- and-crime ravaged neighborhoods. The place to put more cops is in the inner cities, not in the suburbs. ${ }^{49}$

\section{"Most communities need more cops about as much as Washington needs more lobbyists...The place to put more cops is in the inner cities, not in the suburbs."}

Federal support for community policing as established in the crime bill is also problematic because it calls into question the rights of states to decide how to fight crime on the local level. Republicans have proposed repealing the 'Cops on the Beat' provisions of the Violent Crime and Law Enforcement Act of 1994 and substituting for it the Taking Back our Streets Act of $1995.5^{50}$ This bill proposes that federal funds go directly to local governments in the form of block grants to be used to fight crime and improve public safety. While community policing is not explicitly mentioned, the bill lists "establishing crime prevention programs" as one of several areas of expenditure,.

The Taking Back Our Streets Act has a different funding scheme than the 1994 Crime Act. Two billion dollars are authorized to be appropriated through the year 2000, with not more than 2.5 percent of the total authorized to be used for administrative expenses. Rather than relying on matching state and local funds, the Republican proposal requires that each local government deposit grant money in a specially designated trust fund. Both the principal and the interest of these trust funds have to be used within two years of first receipt of federal funds. ${ }^{52}$ 
Reaction to Taking Back Our Streets has been mixed. Choctaw, Oklahoma Police Chief John T. Whetsel, whose own department received grants for additional officers under the 1994 Crime Bill, is a supporter of the Republican proposal. He feels that the measure will help local police departments with small budgets enjoy the benefits of federal aid:

The option to use funds for prevention programs, I am sure will interest many agencies, especially if Title IX of the bill eliminates all of the prevention programs of the 1994 Crime Bill. The important thing here is to leave the selection of the uses of these funds in the hands of the local units of government. They are in the best position to know their own needs. ${ }^{53}$

Unfortunately, history does not support the assertion that money given directly to state and local governments for crime fighting will be used well in every instance. The last major fecleral block grant program for crime fighting was the Law Enforcement Assistance Administration (LEAA), established under Title I of the Omnibus Crime Control and Safe Street Act of 1968. LEAA funds could be used by state and local governments for a range of law enforcement efforts from police training to building construction. Because this was a block grant program, the LEAA provided great discretion to states and localities concerning how the money was used. The LEAA was phased out by 1980 amid complaints that funds were not used properly and after the violent crime rate rose during the $1970 \mathrm{~s}^{54}$ Although the 1995 version of the Taking Back the Streets Act contains a provision that the Director of the Bureau of Justice Assistance has the right to inspect records of how grant money is spent, critics still wonder if the Act has enough oversight provisions to ensure responsible use of funds. ${ }^{55}$

Community policing is at the center of politically charged debates between Democrats and Republicans about the scope of federal government involvement in local crime fighting. Amid this controversy, federal funds may become less available for community policing and the continuation of community policing may rely less on mandates issued from the federal level than on activism at the grassroots level. Citizens of several cities have spurred the development of community policing programs. In 1988, residents of the Fairlawn section of Washington, D.C., organized a coalition to combat drug dealing and other criminal activity. Police quickly formed a partnership with the citizen group, and hundreds of citizen patrols now work with the police department to stop crime in the city ${ }^{56}$ In Flint, Michigan, residents demonstrated a willingness to support community policing, even at personal sacrifice. In 1979, this northern working-class city was the site of the Neighborhood Foot Patrol Program, an experiment funded by a $\$ 2.6$ million grant from the Charles Stewart Mott Foundation. After three years, taxpayers voted to pay higher property taxes to continue community policing. In 1985, taxpayers approved a second increase in property taxes to pay for the program. ${ }^{57}$

\section{Community policing is at the center of politically charged debates between Democrats and Republicans about the scope of federal government involvement in local crime fighting.}

\section{Conclusion}

Despite the great diversity of beliefs in the United States, one widely shared hope is that, together, we can solve major social problems. Furthermore, the expectation is that public agencies can and should provide solutions to these problems.

There are many theories explaining why city streets are so dangerous and why social systems from the family to neighborhoods to religious institutions are falling apart. Academics, politicians, clergy, teachers, parents, young people, and many others are searching for solutions. Community policing is an attempt by a central force in the urban system, the police department, to play a role in bringing people together in order to help create a climate of safety and optimism in our cities.

Law enforcement officials and politicians can debate the merits of one crime control and prevention philosophy versus another, and each crime fighting technique-from the most moderate to the most severe-has some demonstrable ability to deter criminals from committing illegal acts. Admittedly, a combination of tough laws and vigorous community outreach work has proven effective in controlling the escalation of violent urban crime. However, one issue is still unresolved: no proposed course of local action, including community policing, will provide a longterm solution to the crime problem as long as the larger systems that cause economic and spiritual devastation of whole communities remain unchallenged. $\star$ 


\section{Notes}

II wish to thank my editor, Detbie Bergh, for her great patience and dedication to this profect. I would also like to thank Bob Zahradnik and Jennifer Miller for their work as associate eclitors, and Philip Bransford for communicating his confidence in my abilities.

'Department of Justice, Federal Bureau of Investigation, Crime in the United States, 1993: Uniform Crime Reports (Washington, D.C. Government Printing Office, 1994), 7 .

'Department of Justice, Bureau of Justice Statistics, Crime Rate Essentially Unchanged This Year (Washington, D.C., 1994), 2; Department of Justice, Federal Bureau of Investigation, 12.

${ }^{3}$ Department of Justice, Federal Bureau of Investigation, 4.

Mark H. Moore and Robert C. Trojanowicz, "Policing and the Fear of Crime," Perspectives on Policing, no. 3, Publication of the National Institute of Justice, U.S. Department of Justice, and the Program in Criminal Justice Policy and Management, John F, Kennedy School of Government, (Washington, D.C.: U.S. Department of Justice, June 1988), 3.

'Donna Hunzeker, "Combating a Culture of Violence," State Legislatures, March 1994, 16; House Judiciary Committee, Subcommittee on Crime, testimony prepared by Chief of Police, Dallas Police Department, Bennie R. Click, 104th Cong., 1st sess., 1995; Robert D. Crutchfield, "Labor Stratification and Violent Crime," Social Forces 68 (1989): 490-4; Donna Hunzeker, 16.

${ }^{6}$ House Judiciary Committee, Subcommittee on Crime, testimony of Bennie Click, 1.

National Institute of Justice, Community Policing (Washington, D.C.: U.S. Department of Justice, August 1992), 3.

${ }^{B}$ Mark H. Moore and Robert C. Trojanowicz, "Corporate Strategies for Policing" Perspectives on Policing, no. 6, Publication of the National Institute of Justice, U.S. Department of Justice and the Program in Criminal Justice Policy and Management, John F. Kennedy School of Gowernment, Harvard University. (Washington, D.C.: November 1988), 11.

Robert Trojanowicz, Preventing Citil Disturbances: A Community Policing Approacb, Community Policing Series, no. 18 (Michigan: National Center for Community Policing, Michigan State University, 1989), 17 .

"Lee P. Brown, "Community Policing: A Practical Guide for Police Officials," Perspectives on Policing, no. 12, Publication of the National Institute of Justice, U.S. Department of Justice and the Program in Criminal Justice Policy and Management, John F. Kennedy School of Government, Harvard University. (Washington D.C.: September 1989), 8 .
"Robert Trojanowicz et al, The Neighborbood Neturork Center: Part One. Basic Issues and Planning and Implementation in Lansing, Michigan, Community Policing Series, no, 23 (Michigan: National Center for Community Policing, Michigan State Univ., 1988), 5.

${ }^{12}$ Hubert Williams and Patrick V. Murphy, "The Evolving Strategy of Policing: A Minority View," Perspectives on Policing, no. 13. Publications of the National Institute of Justice, U.S. Department of Justice and the Program in Criminal Justice Policy and Management, John F. Kennedy School of Government, Harvard University (Washington, D.C.: January, 1990), 3.

${ }^{1}$ George L., Kelling and William J. Bratton, "Implementing Community Policing: The Administrative Problem," Perspectives on Policing, no. 17. Publications of the National Institute of Justice, U.S. Department of Justice and the Program in Criminal Justice Policy and Management. John F. Kennedy School of Government, Harvard University. (Washington, D.C.: July 1993), 3.

Michael K. Brown, Working the Street (New York: Russell Sage Foundation), 42-3.

${ }^{15}$ Robett Trojanowicz et al, The Neigbborbood Netuork Center: Part One. Basic Issues and Planning and Implementation in Lansing, Micbigan, Community Policing Series no. 23 (Michigan: Michigan State University, undated), 9.

${ }^{3}$ Huber Willams and Patrick V. Murphy, "The Evolving Strategy of Police: A Minority View," Perspectives on Policing, no. 13, Publication of the National Institute of Justice, U.S. Department of Justice and the Program in Criminal Justice Policy and Management, John F. Kennedy School of Government, Harvard University (Washington, D.C.: January 1990), 2-4.

"Brown, Working the Street, 10.

"John J. Dilulio, "A Limited War on Crime That We Can Win," Brookings Review 10 (1992), 7-8.

"Ibid., 8.

"David E. Barkw et al., "Long Economic Cycle and the Criminal Justice System." Crime, Law and Social Change 19, no. 2 (March 1993), 143.

"Difulio, "A Limited War on Crime That We Can Win," 8.

${ }^{2}$ Dennis Jay Kenney, Police and Policing: Contemporary Issues (New York: Prateger Publishers, 1989), 274-5.

Bureau of Justice Assistance, "Understanding Community Policing: A Framework for Action," Monograpb NCJ 14857 (Washington, D.C.: Bureau of Justice Assistance 1993), 7-9.

"George L. Kelling and William J. Bratton, "Implementing Community Policing: The Administrative Problem," Perspectites on Folicing, no. 17, Publication of the National Institute of Justice, 
U.S. Department of Justice and the Program in Criminal Justice Policy and Management, John F. Kennedy School of Government, Harvard University (Washington, D.C.: July 1993), 7.

${ }^{25}$ Lee P. Brown, "Violent Crime and Community Involvement," (paper presented at the FBI Conference on Violent Crime and Community Involvement, Quantico, VA, October 1991), Vital Speeches of the Day 58, no. 6 (January 1992), 183.

${ }^{2 \pi}$ Richard E, Overman et al., "The Case for Community Policing," The Police Chief (1994), 20.

${ }^{27}$ When conducting research for this article, the author reviewed several tools designed to help law enforcement administrators evaluate community policing programs. While these evaluation tools contained extensive questions about community policing program implementation, none required that evaluators make quantitative studies of crime rates or quality of life issues. See Brian Stipak, Susan Immer and Maria Blavadetshcer, "Are You Really Doing Community Policing?" Police Chief 61 (October 1994), 115-123, and Monograph 9-10.

${ }^{28}$ Lee P. Brown, "Community Policing: A Practical Guide for Police Officials," 3 .

${ }^{29}$ Richard Larson, "Rapid Response and Community Policing; Are They Really in Conflict?" (Paper builds from presentation at the Seventh Meeting of the Executive Session of Community Policing at Harvard University Kennedy School of Government 17 June 1998), Community Policing Series no. 20 (Michigan: National Center for Community Policing, Michigan State Univ, 1990), 2.

${ }^{30}$ David M. Kennedy, "The Strategic Management of Police Resources," Perspectives on Policing, no. 14, Publication of the National Institute of Justice, U.S. Department of Justice and the Program in Criminal Justice Policy and Management, John F. Kennedy School of Government, Harvard University (Washington, D.C.: January, 1993), 2.

${ }^{31}$ Richard Larson, "Rapid Response and Community Policing," 6.

${ }^{32}$ David M. Kennedy, "The Strategic Management of Police Resources," 3.

${ }^{33}$ Edwin Meese III, "Community Policing and the Police Officer," Perspectives on Policing, no. 15, Publication of the National Institute of Justice, U. S. Department of Justice and the Program in Criminal Justice Policy and Management, John F. Kennedy School of Government, Harvard University (Washington, D.C.: January, 1993), 2.

${ }^{34}$ Department of Justice, National Institute of Justice, Community Policing in Seattle: A Model Partnership Betueen Citizens and Police (Washington, D.C.: Department of Justice, 1992), 1-4.

${ }^{35}$ Stephen Margolis, "Blythe Street Team Makes an Impact," The
Police Cbief 61 (1994), 70.

36ibid., 73.

${ }^{37}$ Senate Committee on the Judiciary, Federal Law Enforcement Priorities, "America's Crime Problem: What Should Washington Do?" 'Testimony prepared by Professor John J. Dilulio, 104th Cong., 1st sess., 1995, 7.

"Dilulio, "A Limited War on Crime That We Can Win," 11.

"David M. Kennedy, "The Strategic Management of Police Resources," 4.

"National Crime Prevention Council, "The Crime Bill: A Commitment to Prevention," Catalyst 14, no. 8 (1994):, 1.

"Violent Crime Control and Law Enforcement Act of 1994, 103rd Cong, 1st sess., H.R. 3355, Congressional Record, 140, no.120, daily ed. (21 August 1994), H8776.

42Ibid, H8777.

${ }^{43}$ Carroll J. Doherty, "Funding for Crime Programs Heads to President," Congressional Quarterly, 20 August 1994, 2456.

"Violent Crime Control Act, H8777.

${ }^{45}$ Violent Crime Control Act, $\mathrm{H} 87778$.

${ }^{46}$ House Judiciary Committee, Subcommittee on Crime, Statement prepared by Chief of Police, John $\mathrm{T}$. Whetsel, for the House Committee on the Judiciary, 104th Cong,, 1st sess., January $1995,5$.

${ }^{47}$ Violent Crime Control Act, 18776.

"John J. DiIulio, "A Crime Bill That Would Work," Wall Street Joumal, 15 February, 1995, A19.

${ }^{49}$ Taking Back Our Streets Act of 1995, 104th Cong., 1st sess., H.R. 3, sec. 101.

subid,

"Taking Back Our Streets Act of 1995, secs. 102-103.

${ }^{22}$ House Judiciary Committee, Subcommittee on Crime, Statement by John T. Whetsel, 4 .

${ }^{53}$ Library of Congress, Congressional Research Service, Crime Control: The Federal Response Issue Brief no. 90078 (Washington, D.C.: Library of Congress, 1995), CRS-2- 3.

"Taking Back Our Streets Act of 1995, sec. 103.

${ }^{55}$ House Select Committee on Narcotics Abuse and Control, Block by Block: A Community Guide to Retaking our streets and Neighborhoods,from Drug Doturs, 102d Cong, 2d sess., 1993, Committee Print, 30. 
${ }^{56}$ Robert Trojanowicz, Marilyn Steele, and Susan Trojanowicz, "Community Policing: A Taxpayer's Perspective," Community

\section{Bibliography}

Barlow, David E., et al. "Long Economic Cycle and the Criminal Justice System." Crime, Law and Social Change. Vol. 19, no. 2. March 1993, 143-169.

Brown, Lee P. "Community Policing: A Practical Guide for Police Officials." Perspectives on Policing, no. 12. Publication of the National Institute of Justice, U.S. Department of Justice, and the Program in Criminal Justice Policy and Management, John F. Kennedy School of Government, Harvard University. Washington, DC: U.S. Department of Justice, September 1989.

"Violent Crime and Community Involvement: Community Policing." Vital Speeches of the Day 58, no. 6 (January 1992), 182-184.

Brown, Michael K. Working the Street. New York: Russell Sage Foundation, 1981.

Crutchfield, Robert D, "Labor Stratification and Violent Crime." Social Forces 68 (1989): 489-512.

Dewitt, Charles B. "Community Policing in Seattle: A Model Partnership Between Citizens and Police." National Insitute of Justice Research in Brief. Washington, DC: U.S. Department of Justice, August 1992.

DiIulio, John J. "A Crime Bill That Would Work." Wall Street Journal, 15 February, 1995.

"A Limited War on Crime That We Can Win." The Brookings Review 10 (1992): 6- 11.

Doherty, Carroll J. "Funding for Crime Programs Heads to President." Congressional Quarterly 20 August 1994, 2456.

Hunzeker, Donna. "Combating a Culture of Violence." State Legtslatures, March 1994, 14-21.

Kelling, George L. "Police and Communities: the Quiet Revolution." Perspectives on Policing, no. 1. Publication of the National Institute of Justice, U.S. Department of Justice, and the Program in Criminal Justice Policy and Management, John F. Kennedy School of Government, Harvard University, Washington, DC: U.S. Department of Justice, June 1988.

Kelling, George L, and William J. Bratton. "Implementing Community Policing: The Administrative Problem." Perspectives on Policing, no. 17. Publication of the National Institute of Justice, U.S. Department of Justice, and the Program in Criminal Justice Policy and Management, John F. Kennedy School of Government, Harvard University. Washington: U.S. Department of Justice., July 1993.
Policing Series, no. 7, (Michigan: Michigan State University School of Criminal Justice, 1986), 25.
Kelling, George, and Mark H. Moore. "The Evolving Strategy of Policing." Perspectives on Policing, no. 4. Publication of the National Institute of Justice, U.S. Department of Justice, and the Program in Criminal Justice Policy and Management, John F. Kennedy School of Government, Harvard University. Washington, DC: U.S. Department of Justice, November 1988.

Kelling, George L. Robert Wasserman and Hubert Williams. "Police Accountability and Community Policing." Perspectives on Policing, no. 7. Publication of the National Institute of Justice, U.S. Department of Justice, and the Program in Criminal Justice Policy and Management, John F. Kennedy School of Government, Harvard University. Washington, DC: U.S. Department of Justice, November 1988.

Kennedy, David M. "The Strategic Management of Police Resources." Perspectives on Policing, no. 14. Publication of the National Institute of Justice, U.S. Department of Justice, and the Program in Criminal Justice Policy and Management, John F. Kennedy School of Government, Harvard University. Washington, DC: U.S. Department of Justice, January 1993.

Kenney, Dennis Jay. Police and Policing: Contemporary Issues. New York: Praeger Press, 1989.

Larson, Richard C. Rapid Response and Community Policing: Are They Really in Conflict?' Paper builds from presentation at the Seventh Meeting of the Executive Session of Community Policing at Harvard University Kennedy School of Government 17 June 1988. Community Policing Series, no. 20. Michigan: National Center for Community Policing, Michigan State Univ., 1990.

Margolis, Stephen, "Blythe Street Team Makes an Impact." The Police Chief 61 (1994): 70-73.

Meese III, Edwin. "Community Policing and the Police Officer." Perspectives on Policing, no. 15. Publication of the National Institute of Justice, U.S. Department of Justice, and the Program in Criminal Justice Policy and Management, John F. Kennedy School of Government, Harvard University. Washington, DC: U.S. Department of Justice, January 1993.

Moore, Mark H., and Robert C. Trojanowicz. "Corporate Strategies for Policing." Perspectives on Policing, no. 6. Publication of the National Institute of Justice, U.S. Department of Justice, and the Program in Criminal Justice Policy and Management, John F. Kennedy School of Government, Harvard University. Washington, DC: U.S. Department of Justice, November 1988. 
"Policing and the Fear of Crime." Perspectives on Policing, no. 3. Publication of the National Institute of Justice, U.S. Department of Justice, and the Program in Criminal Justice Policy and Management, John F. Kennedy School of Government, Harvard University. Washington, DC: U.S. Department of Justice, 1988.

National Crime Prevention Council. "The Crime Bill: A Commitment to Prevention." Catalyst, Vol. 14, no. 8. Washington, DC: National Crime Prevention Council, 1994.

Overman, Chief Richard E, et al. "The Case for Community Policing." The Police Cbief. January 1994: 20-22.

Sparrow, Malcom K. "Information Systems and the Development of Policing." Perspectives on Policing, no, 16. Publication of the National Institute of Justice, U.S. Department of Justice, and the Program in Criminal Justice Policy and Management, John F. Kennedy School of Government, Harvard University. Washington, DC: U.S. Department of Justice, March 1993.

Stipak, Brian, Susan Immer, and Maria Clavadetscher. "Are You Really Doing Community Policing?" The Police Chief 61 (October 1994): 115-123.

Trojanowicz, Robert. Preventing Civil Disturbances: A Community Policing Approach. Community Policing Series, no. 18. Michigan: National Center for Community Policing, Michigan State Univ., 1989.

Trojanowicz, Robert, et al. The Neighborbood Network Center: Part One-Basic Issues and Planning and Implementation in Lansing, Micbigan. Community Policing Series, no. 23. Michigan: National Center for Community Policing, Michigan State Univ., 1988.

Trojanowicz, Robert, and David Carter. The Pbilosopby and Role of Community Policing. Community Policing Series, no. 13. Michigan: Michigan State Univ. National Neighborhood Foot Patrol Center, 1988.

Trojanowicz, Robert, Marilyn Steele, and Susan Trojanowicz. Community Policing: A Taxpayer's Perspective. Community Policing Series, no. 7. Michigan: Michigan State University School of Criminal Justice, 1986.

U.S. Department of Justice, Bureau of Justice Assistance. Understanding Community Policing: A Framework for Action. Washington, DC: Bureau of Justice Assistance, 1994.
- Bureau of Justice Assistance. "The Systems Approach to Crime and Drug Prevention: A Path to Community Policing," Bulletin Bureau of Justice Assistance 1, no. 2 (1993), 1-7.

Bureau of Justice Statistics. "Crime Rate Essentially Unchanged Last Year." Washington, DC: 1994.

National Institute of Justice. Community Policing. Washington, DC: U.S. Department of Justice, August 1992.

U.S. Library of Congress. Congressional Research Service. Crime Control: The Federal Response. ed., Suzanne Cavanagh, Government Division. Issue Brief no. 90078, 1995.

U.S. House. Violent Crime Control and Law Enforcement Act of 1994. 103d Cong., 2d sess., H.R. 3355. Congressional Record, 140 , no. 120, daily ed. (21 August 1994): H8771- H8878.

1st sess., H.R. 3.

U.S. House Judiciary Committee. Subcommittee on Crime, testimony prepared by Chief of Police, Dallas Police Department, Bennie R. Click, 104th Cong., 1st sess., 1995.

U.S Senate Committee on the Judiciary. Federal Law Enforcement Priorities. Testimony prepared by FBI Director Louis J. Freeh. 104th Cong., 1st sess., 1995.

Federal Law Enforcement Priorities. "America's Crime Problem: What Should Washington Do?" Testimony prepared by Professor John J. Dilulio. 104th Cong., 1st sess, 1995.

U.S. Senate Select Committee on Narcotics Abuse and Control. Block by Block: A Community Guide to Retaking Our Streets and Neighborboods from Drug Dealers. 102d Cong., 2d sess., 1993. Committee Print.

Whetsel, Chief John T'. Testimony prepared for the Subcommittee on Crime of the House Committee on the Judiciary, 104th Cong., 1st sess., 1995.

Williams, Hubert, and Patrick Murphy. "The Evolving Strategy of Police: A Minority View." Perspectives on Policing, no. 13. Publication of the National Institute of Justice, U.S. Department of Justice, and the Program in Criminal Justice Policy and Management, John F. Kennedy School of Government, Harvard University. Washington, DC: U.S. Department of Justice, January 1990. 